\title{
A TRPC3 blocker, Pyr3, prevents stent-induced arterial remodeling
}

\author{
Sarah König ${ }^{1}$, Sara Browne ${ }^{1}$, Heinrich Mächler ${ }^{2}$, Gerald Höfler ${ }^{3}$, C Oliver Kappe ${ }^{4}$, Toma N Glasnov ${ }^{4}$, Marlen Braune ${ }^{5}$ \\ Eric Wittchow ${ }^{5}$, Klaus Groschner ${ }^{1 *}$ \\ From 18th Scientific Symposium of the Austrian Pharmacological Society (APHAR). Joint meeting with the \\ Croatian, Serbian and Slovenian Pharmacological Societies. \\ Graz, Austria. 20-21 September 2012
}

\section{Background}

TRPC-mediated $\mathrm{Ca}^{2+}$ entry has been implicated in the control of smooth muscle proliferation and might represent a pivotal mechanism underlying in-stent restenosis. As we have observed significant expression of TRPC3 in human smooth muscle from coronary arteries as well as from aorta, we tested the efficiency of a recently discovered TRPC3-selective $\mathrm{Ca}^{2+}$ entry blocker, Pyr3 $(10 \mu \mathrm{M})$ to prevent vascular smooth muscle proliferation and stent implantation-induced hyperplasia of human aorta.

\section{Methods and results}

The effect of Pyr3 on proliferation was measured by detection of BrDU incorporation and PCNA expression in human coronary smooth muscle and microvascular endothelium, which displays significantly smaller expression levels of TRPC as compared to smooth muscle. Pyr3 inhibited smooth muscle proliferation with an $\mathrm{IC}_{50}$ of about $3 \mu \mathrm{M}$ but lacked detectable effects on endothelial proliferation. Measurements of ATP-induced $\mathrm{Ca}^{2+}$ signals revealed that Pyr3 suppressed agonist-induced $\mathrm{Ca}^{2+}$ entry more effectively in vascular smooth muscle as compared to endothelial cells. Inhibitory effects of Pyr3 on stent implantation-induced arterial injury were tested using a novel in vitro model of in-stent hyperplasia in human arteries based on organ-typical culture of human aortic constructs. Pyr3 $(10 \mu \mathrm{M})$ effectively prevented increases in tissue levels of proliferation markers (PCNA and Ki67) at 2 weeks after stent implantation into human aortae. Similarly, proliferation markers were significantly suppressed when implanting a Pyr3-releasing stent prototype as compared to a bare metal stent control.

\footnotetext{
* Correspondence: klaus.groschner@medunigraz.at

${ }^{1}$ Institute of Biophysics, Medical University of Graz, 8010 Graz, Austria

Full list of author information is available at the end of the article
}

\section{Conclusions}

Our results suggest TRPC3 as a potential target for pharmacological control of smooth muscle proliferation. Selective inhibition of TRPC $\mathrm{Ca}^{2+}$ entry channels in vascular smooth muscle is suggested as a promising strategy for in-stent restenosis prevention.

\section{Author details \\ 'Institute of Biophysics, Medical University of Graz, 8010 Graz, Austria. ${ }^{2}$ Department of Cardiac Surgery, Medical University of Graz, 8036 Graz, Austria. ${ }^{3}$ Institute of Chemistry, Karl-Franzens University of Graz, 8010 Graz, Austria. Institute of Pathology, Medical University of Graz, 8036 Graz, Austria. ${ }^{5}$ Vascular Interventions R\&D Group, BIOTRONIK SE \& Co. KG, 91052 Erlangen, Germany.}

Published: 17 September 2012

doi:10.1186/2050-6511-13-S1-A85

Cite this article as: König et al:: A TRPC3 blocker, Pyr3, prevents stentinduced arterial remodeling. BMC Pharmacology and Toxicology 2012 13(Suppl 1):A85.

Submit your next manuscript to BioMed Central and take full advantage of:

- Convenient online submission

- Thorough peer review

- No space constraints or color figure charges

- Immediate publication on acceptance

- Inclusion in PubMed, CAS, Scopus and Google Scholar

- Research which is freely available for redistribution

Submit your manuscript at www.biomedcentral.com/submit
C Biomed Central

\section{Biomed Central}

(c) 2012 König et al; licensee BioMed Central Ltd. This is an Open Access article distributed under the terms of the Creative Commons Attribution License (http://creativecommons.org/licenses/by/2.0), which permits unrestricted use, distribution, and reproduction in any medium, provided the original work is properly cited. 